\title{
EDITORIAL
}

\section{In This Issue: The Nourishment and Support of Family Medicine}

\author{
Deborab J. Coben, PhD, Associate Editor \\ Jobn J. Frey III, MD, Associate Editor \\ Ann Fam Med 2010;8:194-195. doi:10.1370/afm.1123.
}

\begin{abstract}
A bouse is not a bome unless it contains food and fire for the mind as well as the body.

Benjamin Franklin
\end{abstract}

W

hen people talk about buying a new house, they express concerns about the aesthetics or durability of the structure, about the living space or the small, strangely configured kitchen (the heart of the home). Someone will say reassuringly, "This house will become a home as you live in it. You will make this house a home." The Annals has been an important contributor to the larger dialogue on the usefulness of the terminology around the medical home in advancing the mission of family medicine. Annals authors have provided insights into not only the principles of the patient-centered medical home (PCMH) but also how, in the midst of codification, we risk losing what is at the heart of family medicine. ${ }^{1}$ By creating strong relationships among clinicians, practice staff, patients, and families, family medicine offers one source of "food and fire" for those both providing and receiving care. This issue of the Annals should add substantially to the conversation. Also adding to the conversation is a supplement this May highlighting research into a major practice redesign project on the medical home. ${ }^{2}$ The supplement evaluates the country's first national demonstration of $\mathrm{PCMH}$ concepts and offers findings that can inform ongoing and future efforts to transform primary care and health care systems.

\section{When Your House Is Not a Home}

Three articles in this issue remind us that we cannot assume that one's house is always a safe and nurturing home and remind us that life without a safe and supportive haven can have important implications for health and well-being.

Mouton and colleagues ${ }^{3}$ show how prolonged exposure to physical or psychological abuse in personal relationships is an important factor in caring for patients with depression. In a longitudinal study of postmenopausal women, they point out that the effects of abuse can continue long after the abusive relationship ends. Asking about a history of abuse in women may hold a key to understanding how to address their current depression.

Furler and colleagues ${ }^{4}$ emphasize the need to understand current illness in the context of past social experiences as they show how the everyday experience of social isolation and violence affects health and wellbeing. Physicians interviewed in the study describe how refugee patients' settlement experiences and the extent of their isolation in the community are related to sadness and depression and that their patients understand depression to be relational, not individual ${ }_{i}$ depression is a manifestation of community, family, and social factors. For clinicians, understanding this relational conceptualization of depression helps treatment, even where cultural differences and seemingly intractable social problems are enormous barriers.

Kerse and colleagues ${ }^{5}$ also highlight the idea that depression can be a relational phenomenon. In their study of older people with depression, participants who received an individualized physical activity program or a social visit (as a control) both experienced improvements in mood and quality of life.

\section{The Food and Fire of Family Medicine}

It is in the context of the work by Mouton et al, Furler et al, and Kerse et al that the article by Baik and colleagues ${ }^{6}$ might be best understood. Most, if not all, diagnostic instruments for depression evaluate individual manifestations of this condition (eg, "Are you feeling sad or blue?"). Baik and colleagues, exploring how and for what purposes primary care clinicians use depression diagnostic instruments, find that physicians use standardized instruments for depression only when they need to persuade a patient to accept his or her depression, when they lack time, or when they do not fully understand the patient's social and relational life. Diagnostic assessment tools are not as useful when 
family medicine is a home, where relationships run deep enough to identify and appreciate what is going on in patients' lives and to come together in partnership to negotiate appropriate interventions.

Family relationships, of course, count, too. McKee and colleagues ${ }^{7}$ elegantly highlight the tensions and trade-offs that parents must navigate when trying to feed their children healthy food and keep them physically active. When my (D.J.C.) 10-year old daughter asked, "Can we have a day when we eat white food: white bread, white pasta, white rice all day?" what I particularly liked was the way she framed her complaint about our whole-grain diet as a suggestion for a day off. McKee et al point out that some families need practical strategies for making healthy eating and exercise a part of their busy and complicated lives, and family doctors still have an important role in this process. Family medicine is a home when it provides the nourishment and support that people need to lead healthy lives and raise healthy kids. As support for this concept, Cohen and $\mathrm{Coco}^{8}$ use US national ambulatory data to show that family doctors have a consistent role in caring for children, even with the decreasing numbers who provide maternity care. These reassuring data highlight the opportunities that will continue to be there for family physicians to work with parents on issues of food and exercise-and strategies like allowing an all-white-food day occasionally.

While home is also a place where people can help you make sense of life when it feels chaotic and confusing, Buckley and colleagues ${ }^{9}$ show how patients on chronic narcotic therapy for noncancer pain are often shortchanged in the provision of preventive care. This study should alert us to look beyond chronic pain to make sure patients get the preventive care they deserve.

Finally, a large study from the Netherlands ${ }^{10}$ on the cause of dizziness in the elderly comes to the surprising conclusion that cardiovascular illness is the leading cause of presyncope and that adverse drug reactions are a close second. This knowledge should make us increase our surveillance of older patients for heart disease and work to minimize unnecessary and potentially harmful prescriptions of all types.

\section{Three Essays}

Hoong's story of being transformed by an acute ischemic stroke ${ }^{11}$ shows how treatment requires great aptitude and appropriate use of high-tech diagnostic and treatment tools. But life-threatening illness also requires talking with patients and families, sharing and showing emotions, offering words of encouragement, and sometimes blurring the boundaries in our own families. Schmittdiel ${ }^{12}$ suggests a novel use for participatory research-seeing health systems as com- munities. The strategies of approaching subjects as coproducers of research operate much as they do with more traditional applications of participatory research methods. And the essay by Swindell and McGuire ${ }^{13}$ will undoubtedly generate discussion on the proper role for physicians in convincing patients to act in the patients' own best interests. At a minimum, the authors raise the issue of what Michael Balint termed "the apostolic function" of the physician to convince the patient of the correctness of the doctor's point of view and how that perspective holds some peril for both patient and doctor. ${ }^{14}$

Please join the online discussion of these articles at http://www.AnnFamMed.org.

To read or post commentaries in response to this article, see it online at http://www.annfammed.org/cgi/content/full/8/3/194.

\section{References}

1. Frey JJ III. In this issue: relationships count for patients and doctors alike. Ann Fam Med. 2010;8(2):98-99.

2. Bayliss EA, Phillips WR, eds. Evaluation of the American Academy of Family Physicians' patient-centered medical home National Demonstration Project. Ann Fam Med. In press.

3. Mouton CP, Rodabough R, Rovi S, Brzyski R, Katerndahl DA. Psychosocial effects of physical and verbal abuse in postmenopausal women. Ann Fam Med. 2010;8(3):206-213.

4. Furler J, Kokanovic R, Dowrick C, Newton D, Gunn J, May C. Managing depression among ethnic communities: a qualitative study. Ann Fam Med. 2010;8(3):231-236

5. Kerse N, Hayman K, Moyes S, et al. Home-based activity program for older people with depressive symptoms: DeLLITE-a randomized controlled trial. Ann Fam Med. 2010;8(3):214-223.

6. Baik S, Gonzales J, Bowers BJ, Anthony J, Tidjani B, Susman JL. Reinvention of depression instruments by primary care clinicians. Ann Fam Med. 2010;8(3):224-230.

7. McKee M, Maher S, Deen D, Blank A. Counseling to prevent obesity among prechool children: acceptability of a pilot urban primary care intervention. Ann Fam Med. 2010;8(3):249-255

8. Cohen D, Coco A. Trends in well-child visits to family physicians by children younger than 2 years of age. Ann Fam Med. 2010;8(3):245-248

9. Buckley DI, Calvert J, Lapidus J, Morris C. Chronic opioid therapy and preventive services in rural primary care: an Oregon rural practice-based research network study. Ann Fam Med. 2010;8(3):237-244.

10. Maarsingh OR, Dros J, Schellevis F, et al. Causes of persistent dizziness in elderly patients in primary care. Ann Fam Med. 2010; 8(3):196-205.

11. Sharma VK, Hoong L. Journey during acute ischemic stroke: a physician's experience. Ann Fam Med. 2010;8(3):265-267.

12. Schmittdiel JA, Grumbach K, Selby J. System-based participatory research in health care: an approach for sustainable translational research and quality improvement. Ann Fam Med. 2010;8(3): 256-259.

13. Swindell JS, McGuire AL, Halpern SD. Beneficent persuasion: techniques and ethical guidelines to improve patients' decisions. Ann Fam Med. 2010;8(3):260-264.

14. The Doctor, His Patient and the Illness. London: Churchill Livingstone, 1957. 